\title{
Recent Advances in Latin American Cooperation in Behavioral Sciences: A Documentary Study
}

\section{Agnaldo García', Beatriz de Barros-Souza', Juliana Berzin?', Jussara Abilio-Galvão', Julia Sursis Nobre Ferro Bucher-Maluschke² y Wilson López-López ${ }^{3 *}$}

' Federal University of Espírito Santo, Vitória, Brazil

${ }^{2}$ Catholic University of Brasília, Brasília, Brazil

${ }^{3}$ Pontificia Universidad Javeriana, Colombia

- Recibido: 21 - 06 - 2018 . Aceptado: $26-10-2018$. Avance online: $22-11-2018$

ABSTRACT: A survey based on PsycINFO from 2011 to 2015 identified 809 publications resulting from scientific cooperation between at least two countries in Latin American Behavioral Sciences, including 770 journal articles, 36 chapters and 3 books. In relation to the articles a total of 3,926 authorial participations were registered. The countries with the highest participation were Brazil, Argentina, Mexico, Colombia, and Chile. The 770 articles included 318 exclusively Latin American productions and 452 publications with the participation of one or more countries from other continents. The three areas that showed the largest number of publications were Psychological and Physical Disorders (283), Health and Mental Health: Treatment and Prevention (137), and Physiological Psychology and Neuroscience (94). The 770 articles identified were published in 354 journals, but only 26 journals published five or more articles resulting from Latin American cooperation in the period. Only three Latin American journals on Psychology are listed among the top 26. The data are analyzed and discussed in view of possible ways to expand cooperation.

KEYWORDS: Psychology; Cooperation; Latin America; Research; Publications.

Avances recientes en la cooperación latinoamericana en ciencias comportamentales: un estudio documental

RESUMEN: Una encuesta basada en Psycinfo de 2011 a 2015 identificó 809 publicaciones resultantes de la cooperación científica entre al menos dos países latinoamericanos en Ciencias del Comportamiento, incluyendo 770 artículos, 36 capítulos y 3 libros. En relación a los artículos se registraron un total de 3.926 participaciones autorales. Los países con mayor participación fueron Brasil, Argentina, México, Colombia y Chile. Los 770 artículos incluían 318 producciones exclusivamente latinoamericanas y 452 publicaciones con la participación de uno o más países de otros continentes. Las tres áreas que mostraron el mayor número de publicaciones fueron Trastornos Psicológicos y Físicos (283), Salud y Salud Mental: Tratamiento y Prevención (137), y Psicología Fisiológica y Neurociencia (94). Los 770 artículos identificados fueron publicados en 354 revistas, pero sólo 26 revistas publicaron cinco o más artículos resultantes de la cooperación latinoamericana en el período. Sólo tres revistas latinoamericanas de Psicología figuran entre las 26 principales. Los datos son analizados y discutidos en vista de las posibles formas de ampliar la cooperación.

PALABRAS CLAVE: Psicología; Cooperación; América Latina; Investigación; Publicaciones.

The proportion of scientific papers internationally coauthored has more than doubled in 20 years, with the participation of

*Correspondence: Wilson López-López.

Pontificia Universidad Javeriana, Colombia.

CP: 110231 , Bogotá, Colombia.

E-mail: lopezw@javeriana.edu.co

(C) 2018 Sociedad Universitaria de Investigación en Psicología y Salud. Publicado por Consejo General de Colegios Oficiales de Psicólogos, España. Este es un artículo Open Access
bajo la CC BY-NC-ND licencia (http://creativecommons.org/licencias/by-nc-nd/4.0/)

Citar como/Cite as: García, A de Barros-Souza, B, Berzin, J., Abilio-Galvão, J., Sursis Nobre Ferro Bucher-Maluschke., J. \& López-López., W. (2019). Recent Advances in
Nolis Latin American Cooperation in Behavioral Sciences: A Documentary Study. Revista Iberoamericana de Psicología y Salud, 10 (1), 37-47. https://doi.org/10.23923/i. rips.2018.02.024 more people and countries in international cooperation (Wagner, Park, \& Leydesdorff, 2015). International co-authorship also increases the citation impact of publications of both young and old institutions (Khor \& Yu, 2016). RondaPupo, Díaz-Contreras, Ronda-Velázquez, and Ronda-Pupo (2015) found a positive relationship between academic collaboration and the impact of Latin American and the Caribbean research 
articles on management, published between 1990 and 2010 in JCR (Journal Citation Report) journals. Articles resulting from collaboration present on average 1.22 times more impact than single authored papers. The level of collaboration is also positively correlated to impact and articles resulting from international collaboration have 1.59 times more impact than those resulting from domestic cooperation.

Although international cooperation is usually seen as positive for those involved, the participation and advantages for developing countries have also been addressed in the literature. Zanotto, Haeffner, and Guimarães (2016), for instance, present a criticism towards unbalanced international collaboration, suggesting the need for a more participative contribution of all partners to face local and regional challenges, to promote their development and to contribute to solve national problems. Kreimer (2016), discussing scientific investigation on Chagas Disease as a specific Latin American problem, also analyzes some problems related to international scientific cooperation with colleagues from developed countries, who are interested in their knowledge products but not in the local concerns of developing countries.

International cooperation in Psychology is growing, as in science in general (Wagner, 2006). Kliegl and Bates (2011) based on articles published from 1975 to 2007, pointed out a remarkable increase of internationally coauthored publications in 12 major Psychology journals. On the other hand, international cooperation in Psychology in Latin and IberoAmerica is still small. Regarding lbero American publications from 2005 to 2007, López-López, García-Cepero, Aguilar-Bustamante, Silva and Aguado (2010) report low levels of international cooperation, indicating that in $92 \%$ of articles, partnerships occurred within the same country. López-López, Silva, García-Cepero, AguilarBustamante and Aguado (2011) also pointed out low levels of international cooperation in Latin American Psychology, based on articles published in Latin American journals from 2005 to 2007.

Some papers have presented data about Latin and Iberoamerican Psychology, but without discussing scientific cooperation. For instance, García-Martínez, Guerrero-Bote and MoyaAnegón (2012) observed that less than 20\% of the world's countries publishing in Psychology cover over $98 \%$ of the total world production. The U.S. is the leading producer, followed by the U.K. and Canada, representing more than 60\% of the total production, followed by Germany, Austria, and the Netherlands. The production of these countries exceeds $70 \%$ of world production in Psychology. Quevedo-Blasco and López-López (2011) investigated the visibility and popularity of scientific journals in psychology published in Latin American countries, according to a recent Journal Citation Reports (JCR) 2010, including 18 journals. The Latin American journal that obtained the highest indexed IF was the International Journal of Clinical and Health Psychology $(1,842)$. A third paper discussed the internationality of Iberoamerican journal on Psychology. Zych and Buela-Casal (2010) concluded that the most international journal in Iberoamerica is the Revista Latinoamericana de Psicología, followed by The Spanish Journal of Psychology, Psicothema and Universitas Psychologica. Although discussing the criteria for internationality, international scientific cooperation is not under discussion. Further information about Latin American journals included in the Redalyc may be found in LópezLópez, Aguilar-Bustamante, Aguado-López, and Becerril- García (2016) and in the website http:// fiap.redalyc.org

López-López, Anegón, Acevedo-Triana, Garcia and Silva (2015) analyzed the levels of collaboration in Iberoamerican Psychology, including local and international collaboration, based on data from the Scopus database. National cooperation was the most common level of cooperation among Iberoamerican psychologists and it was more expressive than international cooperation.

Cuartas, Arias, and Leydesdorff (2016) compared the visibility of Latin American and Caribbean publications in the Core Collection indexes of the Web of Science and the SciELO Citation Index, and suggest that regional cooperation in Latin American Psychology is more visible in the second database. In the Web of Science, authors from these areas are integrated at the global level in international networks, while in SciELO interactions among researchers from Latin America and the Caribbean are more visible. Based on the data from the Web of Science, researchers from Latin America and the Caribbean cooperate mainly with peers from North America and Europe, while regional cooperation 
with authors from other Latin American and Caribbean countries is not important, and even less relevant than cooperation with Asia, Africa, and Oceania. On the other hand, data from SciELO show more regional cooperation than data from the Web of Science publications. According to the authors, these collaborations are important in order to exchange resources and ideas with other developing countries to try to solve similar problems. These data also reveal that the structure and functioning in Latin American cooperation should be further investigated. The need for integration and cooperation in Latin American Psychology has been discussed in the last years (Koller, Sarriera \& Silva Neto, 2008), but publications were limited to describe the situation of research and scientific production in Psychology in some countries, such as Paraguay (Martínez, 2008), Colombia (Puche-Navarro, 2008) and Peru (Livia, 2008).

Some publications have analyzed different aspects of Latin American cooperation in Psychology. Garcia, Acevedo-Triana and LópezLópez (2015), for instance, investigated the meaning of cooperation among Latin American researchers in Psychology and their proposals to promote cooperation. The investigation was based on the written reports of 26 researchers who had already published an article in cooperation with a partner from other Latin American country. The data were subjected to thematic analysis and the authors identified seven themes related to the meaning of partnerships with other Latin American authors: (1) advantages of Latin American scientific cooperation; (2) cultural exchange and network formation and expansion; (3) knowledge and resource sharing; (4) comparing results, diversity, and theory validation; (5) collaboration in (graduate) education and scientific events; (6) scientific impact; and, (7) social and political impact: national, regional, and international. The proposals presented by the researchers to facilitate Latin American cooperation in Psychology were classified into eight thematic groups: (1) organization and participation in events, (2) associations and cooperation networks and increased communication, (3) investment in science and international scientific cooperation, (4) administrative issues, (5) joint research projects and programs, (6) exchange of students and researchers, (7) international cooperation in education, and, (8) dissemination of Latin American scientific knowledge. The authors concluded that scientific cooperation in Latin America had a multifaceted meaning and different strategies in different levels are proposed to foster cooperation, involving not only scientific research, but also educational cooperation and the organization of scientific events.

Garcia, López-López, Acevedo-Triana and Bucher-Maluschke (2016) investigated some aspects of Latin American cooperation in the behavioral sciences, including the motivation for establishing partnerships, how these partnerships are evaluated by their participants, and the difficulties encountered. Participants were a hundred Latin American researchers who had already cooperated with other Latin American authors, based on data from Psycinfo from 2001 to 2010 who answered a questionnaire. The main reasons for establishing these partnerships were to reach broader and more significant results, increased productivity and higher visibility and recognition of their scientific production. Most participants recognized that cooperation resulted in more publications and publications of higher scientific level and greater visibility. Difficulties included access and communication, the final writing of the paper, and data collection. The main barriers were financial constraints and lack of time.

An investigation about Latin American cooperation in the behavioral sciences for the period from 2001 to 2010 was conducted by Garcia, Acevedo-Triana and Lopez-Lopez (2014), and a summary of the main results found are reported here. Based on a documentary investigation using data from Psycinfo database for the period 2001-2010, the authors identified 528 publications resulting from Latin American cooperation. They have also reported 2,154 Latin American authorial participations (reporting how many times authors from each country were cited, including repetitions). Countries with the larger number of authorial participations were Brazil (609 authorial participations), Mexico (367), Argentina (308), Colombia (192), Chile (177), Peru (1 11 ), Uruguay (88), Cuba (79), Venezuela (54), Costa Rica (39), Ecuador (27), Guatemala (26), Honduras (24), Dominican Republic (18), Bolivia (10), Paraguay (9), Panama (8), El Salvador (5), Nicaragua (3). Concerning the range of international cooperation, 281 publications were exclusively Latin American, including authors 
from two Latin American countries (251), three countries (23), or four or more countries (7). Publications with the participation of authors from at least two different Latin American countries with at least one author from other continents were 247, including exclusively PanAmerican publications (84), Ibero-American publications (12), and international publications in cooperation with other countries (151). In the Pan-American publications, authors from the USA participated in 52 and from Canada in 12 of them. In Ibero-American cooperation, only Spain was mentioned (Portugal was not cited).

Garcia, Acevedo-Triana and Lopez-Lopez (2014) also analyzed the main thematic areas, and the 528 publications used 105 different codes attributed by Psycinfo to identify the thematic area, in a total of 623 code uses. The areas are as follows: Psychological and Physical Disorders (176 citations); Health and Mental Health Treatment and Prevention (100); Physiological Psychology and Neuroscience (82); Social Processes and Social Issues (48); Psychometrics, Statistics and Methodology (44); Animal Experimental and Comparative Psychology (44); Developmental Psychology (27); Educational Psychology (21); Professional Psychological and Health Personnel Issues (20); Human Experimental Psychology (16); Industrial and Organizational Psychology (12); Personality Psychology (8); Engineering and Environmental Psychology (6); Consumer Psychology (5); Intelligent Systems (5); Social Psychology (3); General Psychology (2); Communication Systems (2); Military Psychology (1); Forensic Psychology and Legal Issues (1). The codes for Psychology and the Humanities and Sport Psychology and Leisure were not used. Health may be considered the central theme.

The authors (Garcia, Acevedo-Triana \& Lopez-Lopez, 2014) reported a total of 252 journals publishing 520 papers. 157 journals published only one paper, while 95 published two or more articles (363 publications). 16 journals published five or more articles (162 articles). The most important journals were Revista LatinoAmericana de Enfermagem (62), British Journal of Psychiatry (12), Behavioural Brain Research (11), International Review of Psychiatry (8), Journal of Sexual Medicine (8), Revista Latinoamericana de Psicologia (7), Journal of Multivariate Analysis (6), Neurobiology of Learning and Memory (6), Revista
Interamericana de Psicologia (6), The Lancet (6), Acta Psiquiátrica y Psicológica de America Latina (5), Animal Behaviour (5), Behavioural Processes (5), Maturitas (5), Physiology Behavior (5), Psychological Medicine: A Journal of Research in Psychiatry and the Allied Sciences (5). The five top journals are not specifically on Psychology, but are related to Psychiatry, Nursing and Neurosciences.

This article reports and discusses the results of an investigation on international cooperation in behavioral sciences, including Psychology and related sciences, among authors from different Latin American countries based on information from the Psycinfo database, from 2011 to 2015. The following specific objectives are proposed: (a) report the number publications resulting from Latin American cooperation in the period; (b) report the number of authorial participation by Latin American country; (c) report publications resulting from cooperation of at least two exclusively Latin American authors and those involving countries of other continents; (d) identify the main thematic areas based on APA thematic codes; (e) list the main journals that publish articles in cooperation.

In this article, international co-authorship will be used as an indicator of international scientific cooperation (Lopez-Lopez et al., 201 1). According to Katz and Martin (1997), co-authorship is the basic unity to measure collaboration. According to Lemarchand (2016), co-authorship is "one of the most tangible and well-documented forms of scientific collaboration" (p. 37). New ways to describe more accurately cooperation participation and roles in co-authorship have been proposed recently (Allen, Brand, Scott, Altman, \& Hlava, 2014).

\section{METHOD}

This documentary study was based on articles published in scientific journals in Psychology and related areas indexed in Psycinfo with authors from at least two Latin American countries, published between 2011 and 2015 (five years). The articles were identified in Psycinfo in view of the possibility of identifying the affiliation and country of origin of the authors in a specific field and for representing one of the most important international sources of indexation of Psychology journals. This study was based on the method employed by Garcia, Acevedo-Triana and López- 
López (2014), who carried out an analysis for the period between 2001 and 2010. We considered as Latin American authors those affiliated with institutions in the region, regardless of nationality or place of birth of the author. The survey was conducted by crossing the 19 countries considered, two by two, including Argentina, Bolivia, Brazil, Chile, Colombia, Costa Rica, Cuba, Dominican Republic, Ecuador, El Salvador, Guatemala, Honduras, Mexico, Nicaragua, Panama, Paraguay, Peru, Uruguay and Venezuela. Regarding the publications, data were collected on the participating countries, the subject (using APA classification codes), and journal (in the case of articles). The data are presented in a descriptive way. This method to extract information has been used in other investigations (e.g. Mahoney, Buboltz, Calvert y Hoffmann, 2010). During data collection, several data have been recorded, including the complete reference of the article (including journal and year of publication); authors, institutions and countries to which they belong in the case of Latin American authors. The articles have been analyzed to summarize all Latin American authorial participations country by country; the subjects covered, indicated by the APA codes; the journals involved and the range of Latin American partnerships, if restricted to Latin America, or involving authors from other regions, in a quantitative and descriptive way.

\section{RESULTS}

The survey identified 809 publications with the participation of authors from at least two Latin American countries in the period of five years, from 2011 to 2015, published in scientific journals on Psychology and related areas, indexed in Psycinfo database, being 770 articles, 36 chapters and 3 books. In relation to the articles, a total of 3,926 authorial participations were registered, indicating how many times authors were cited, including repetitions of the same author. This paper analyses the 770 articles published in scientific journals.

\section{- COOPERATION IN LATIN AMERICAN BEHAVIORAL SCIENCES: AUTHORS AND COUNTRIES}

The survey indicated a total of 3,926 authorial participations, including repetitions.
Table 1

Authorial participation by country in publications with Latin American cooperation

\begin{tabular}{|c|c|}
\hline Country & Authorial participation \\
\hline Brazil & 901 \\
\hline Argentina & 672 \\
\hline Mexico & 624 \\
\hline Colombia & 478 \\
\hline Chile & 377 \\
\hline Cuba & 205 \\
\hline Peru & 167 \\
\hline Uruguay & 133 \\
\hline Ecuador & 64 \\
\hline Costa Rica & 60 \\
\hline Venezuela & 48 \\
\hline Guatemala & 41 \\
\hline Bolivia & 29 \\
\hline Dominican Republic & 26 \\
\hline Honduras & 26 \\
\hline El Salvador & 22 \\
\hline Paraguay & 20 \\
\hline Nicaragua & 18 \\
\hline Panama & 15 \\
\hline Total & 3,296 \\
\hline
\end{tabular}

Data from the 19 countries investigated are shown in Table 1. The data indicate a great disparity in the participation of the various countries in co-authoring. In absolute terms, Brazil had the largest volume of authorial participations (901), followed by Argentina, Mexico, Colombia and Chile. In relation to the range of participation, two groups were analyzed, one gathering articles written exclusively by Latin American authors from diverse countries, and the other with the participation of authors from at least two Latin American countries, with the participation of one or more authors from other continents.

Considering the 770 articles, $41.3 \%$ (318 articles) were exclusively Latin American productions and 58.7\% (452 articles) were publications of at least two Latin American 
Table 2

The Range of Latin American partnerships

\begin{tabular}{|c|c|}
\hline $\begin{array}{c}\text { Nature of the } \\
\text { Partnership }\end{array}$ & Number of Publications \\
\hline $\begin{array}{c}\text { Exclusively Latin American } \\
\text { Publications } \\
\text { Bilateral }\end{array}$ & 289 \\
Three Countries \\
$\begin{array}{c}\text { Four or more countries } \\
\text { Latin American Publications } \\
\text { with Other Continents } \\
\text { Pan-American } \\
\text { Ibero-American } \\
\text { Other International } \\
\text { Publications }\end{array}$ & 23 \\
\hline Total & 452 \\
\hline
\end{tabular}

countries with participation of another continent, including North America. The 318 articles with Latin American exclusive participation included 289 bilateral collaborations, 23 had the contribution of three Latin American countries and only six articles counted on the cooperation of four or more Latin American countries. 452 articles had the participation of at least two Latin American countries, besides one or more authors from other continents. In this case, 118 articles were Pan-American productions, involving other countries in North America, 47 were Ibero-American productions, involving Spain and/or Portugal, and 287 were international publications of another nature (with two or more Latin American countries with authors from other regions). A summary of the data is shown in Table 2. In the publications involving countries of other regions, besides Latin America, three groups were proposed, due to the colonization and cultural formation of the Latin American countries (IberoAmerican publications) and their geopolitical position (Pan-American publications). There were few publications involving cooperation between two or more Latin American countries that included a country in the Iberian Peninsula, in this case, with the participation of Spain and/or Portugal. This proportion is higher for partnerships between two or more Latin American partners with other nations in North America, especially the United States.
Pan-American publicationstotalled 118 titles, with the participation of the United States in 105 publications and of Canada in 20 publications. Of the 47 Ibero-American publications, Spain participated in 45 partnerships and Portugal only in six publications. In 4 cases, Portugal and Spain participated together. Despite cultural similarities, because of colonization and the shared language (mainly Spanish), Ibero-American partnerships are not as frequent as Pan-American ones.

Table 3

Publications by area of Psychology

\begin{tabular}{|c|c|}
\hline Area & Number of Publications \\
\hline 2100 General Psychology & 02 \\
\hline $\begin{array}{l}2200 \text { Psychometrics \& } \\
\text { Statistics \& Methodology }\end{array}$ & 77 \\
\hline $\begin{array}{l}2300 \text { Human Experimental } \\
\text { Psychology }\end{array}$ & 23 \\
\hline $\begin{array}{l}2400 \text { Animal Experimental \& } \\
\text { Comparative Psychology }\end{array}$ & 33 \\
\hline $\begin{array}{l}2500 \text { Physiological } \\
\text { Psychology \& Neuroscience }\end{array}$ & 94 \\
\hline $\begin{array}{c}2600 \text { Psychology \& the } \\
\text { Humanities }\end{array}$ & - \\
\hline 2700 Communication Systems & 04 \\
\hline $\begin{array}{l}2800 \text { Developmental } \\
\text { Psychology }\end{array}$ & 35 \\
\hline $\begin{array}{l}2900 \text { Social Processes \& } \\
\text { Social Issues }\end{array}$ & 46 \\
\hline 3000 Social Psychology & 11 \\
\hline 3100 Personality Psychology & 25 \\
\hline $\begin{array}{l}3200 \text { Psychological \& } \\
\text { Physical Disorders }\end{array}$ & 283 \\
\hline $\begin{array}{l}3300 \text { Health \& Mental Health } \\
\text { Treatment \& Prevention }\end{array}$ & 137 \\
\hline $\begin{array}{c}3400 \text { Professional } \\
\text { Psychological \& Health } \\
\text { Personnel Issues }\end{array}$ & 21 \\
\hline 3500 Educational Psychology & 39 \\
\hline $\begin{array}{l}3600 \text { Industrial \& } \\
\text { Organizational Psychology }\end{array}$ & 21 \\
\hline $\begin{array}{c}3700 \text { Sport Psychology \& } \\
\text { Leisure }\end{array}$ & 04 \\
\hline 3800 Military Psychology & 03 \\
\hline 3900 Consumer Psychology & 16 \\
\hline $\begin{array}{c}4000 \text { Engineering \& } \\
\text { Environmental Psychology }\end{array}$ & 07 \\
\hline 4100 Intelligent Systems & 11 \\
\hline $\begin{array}{l}4200 \text { Forensic Psychology \& } \\
\text { Legal Issues }\end{array}$ & 04 \\
\hline Total & 896 \\
\hline
\end{tabular}


Table 4

Publications on Psychological and Physical Disorders

\begin{tabular}{|c|c|}
\hline Area and Subarea & Number of Publication \\
\hline $\begin{array}{l}3200 \text { Psychological \& } \\
\text { Physical Disorders }\end{array}$ & 26 \\
\hline 3210 Psychological Disorders & 17 \\
\hline 3211 Affective Disorders & 37 \\
\hline $\begin{array}{l}3213 \text { Schizophrenia \& } \\
\text { Psychotic States }\end{array}$ & 12 \\
\hline $\begin{array}{c}3215 \text { Neuroses \& Anxiety } \\
\text { Disorders }\end{array}$ & 6 \\
\hline 3217 Personality Disorders & 2 \\
\hline $\begin{array}{l}3230 \text { Behavior Disorders \& } \\
\text { Antisocial Behavior }\end{array}$ & 12 \\
\hline $\begin{array}{l}3233 \text { Substance Abuse \& } \\
\text { Addiction }\end{array}$ & 22 \\
\hline $\begin{array}{l}3236 \text { Criminal Behavior \& } \\
\text { Juvenile Delinquency }\end{array}$ & 3 \\
\hline $\begin{array}{l}3250 \text { Developmental } \\
\text { Disorders \& Autism }\end{array}$ & 9 \\
\hline 3256 Mental Retardation & 3 \\
\hline 3260 Eating Disorders & 12 \\
\hline $\begin{array}{c}3280 \text { Environmental Toxins \& } \\
\text { Health }\end{array}$ & 1 \\
\hline $\begin{array}{l}3290 \text { Physical \& Somatoform } \\
\text { \& Psychogenic Disorders }\end{array}$ & 30 \\
\hline $\begin{array}{l}3291 \text { Immunological } \\
\text { Disorders }\end{array}$ & 11 \\
\hline 3293 Cancer & 5 \\
\hline $\begin{array}{l}3295 \text { Cardiovascular } \\
\text { Disorders }\end{array}$ & 6 \\
\hline $\begin{array}{c}3297 \text { Neurological Disorders } \\
\text { \& Brain Damage }\end{array}$ & 66 \\
\hline $\begin{array}{l}3299 \text { Vision \& Hearing \& } \\
\text { Sensory Disorders }\end{array}$ & 3 \\
\hline Total & 283 \\
\hline
\end{tabular}

\section{- MAIN THEMATIC AREAS IN PUBLICATIONS WITH LATIN AMERICAN COOPERATION}

The 770 articles resulting from cooperation between at least two Latin American countries were classified using 123 codes provided by Psycinfo. The American Psychological Association itself classifies publications according to thematic codes by subject area or sub-area. As more than one code can be used for each article, a total of 896 codes were employed for the 770 articles. The thematic area of all articles is indicated in
Table 3. The three areas that brought together the largest number of publications resulting from cooperation including at least two Latin American authors were Psychological and Physical Disorders (283), Health and Mental Health: Treatment and Prevention (137), and Physiological Psychology and Neuroscience (94).

The data about thematic areas indicate a great heterogeneity in the number of publications in each area. The three areas with the largest number of publications account for more than half of the published works (57.4\%). There is one area with no publications with Latin American cooperation and five areas with five or fewer publications. The predominant theme is health. The existing subareas are Psychological and Physical disorders (283).

As in the articles in general, the publications of different areas are also heterogeneously distributed. The Area of Psychological and Physical Disorders may serve as example of heterogeneity in relation to the subtopics, being Neurological Disorders and Brain Damage the most investigated subtopic, followed by Affective Disorders. Other sub-areas have fewer works resulting from Latin American cooperation, suggesting the possibility of expanding this cooperation.

\section{- JOURNALS AND ARTICLES WITH LATIN AMERICAN COOPERATION}

The 770 articles identified were published in 354 journals. 207 journals published a single article, while 147 journals published two or more articles. 54 journals published two articles, 36 published three and 31 published four articles resulting from Latin American cooperation. Only six journals published more than ten articles with Latin American collaboration and 26 published five or more articles. The most important journals, which have published at least five cooperative papers, are listed in Table 5.

Only three Latin American journals on Psychology are listed among the top 26. The five most important journals are not specifically on Psychology, but on Psychiatry, Nursing, Neuroscience and Medicine.

\section{DISCUSSION}

Comparing the data obtained in the present investigation, from 2011 to 2015, with data 
Table 5

Major journals with publications resulting from Latin American cooperation

\begin{tabular}{|c|c|}
\hline Area and Subarea & Number of Publication \\
\hline $\begin{array}{l}\text { 1. Revista Latino-Americana } \\
\text { de Enfermagem }\end{array}$ & 33 \\
\hline 2. The Lancet & 18 \\
\hline 3. PLOS ONE & 15 \\
\hline $\begin{array}{l}\text { 4. Arquivos de Neuro- } \\
\text { Psiquiatria }\end{array}$ & 12 \\
\hline 5. NeuroRehabilitation & 12 \\
\hline 6. Universitas Psychologica & 11 \\
\hline $\begin{array}{l}\text { 7. Journal of Affective } \\
\text { Disorders }\end{array}$ & 9 \\
\hline $\begin{array}{c}\text { 8. Journal of Cross-Cultural } \\
\text { Psychology }\end{array}$ & 9 \\
\hline $\begin{array}{l}\text { 9. Journal of Multivariate } \\
\text { Analysis }\end{array}$ & 8 \\
\hline 10. AIDS and Behavior & 7 \\
\hline $\begin{array}{l}\text { 11. Food Quality and } \\
\text { Preference }\end{array}$ & 7 \\
\hline 12. The Cerebellum & 7 \\
\hline $\begin{array}{l}\text { 13. Avances en Psicología } \\
\text { Latinoamericana }\end{array}$ & 6 \\
\hline $\begin{array}{l}\text { 14. Journal of Business } \\
\text { Research }\end{array}$ & 6 \\
\hline 15. Psychological Medicine & 6 \\
\hline 16. Salud Mental & 6 \\
\hline $\begin{array}{l}\text { 17. The International Journal } \\
\text { of Behavioral Nutrition and } \\
\text { Physical Activity }\end{array}$ & 6 \\
\hline $\begin{array}{l}\text { 18. Applied Animal Behaviour } \\
\text { Science }\end{array}$ & 5 \\
\hline 19. Biological Psychiatry & 5 \\
\hline 20. Bipolar Disorders & 5 \\
\hline $\begin{array}{l}\text { 21. Journal of } \\
\text { Neuroendocrinology }\end{array}$ & 5 \\
\hline $\begin{array}{l}\text { 22. Journal of the } \\
\text { Neurological Sciences }\end{array}$ & 5 \\
\hline 23. Molecular Psychiatry & 5 \\
\hline 24. Neurolmage & 5 \\
\hline $\begin{array}{l}\text { 25. Revista Latinoamericana } \\
\text { de Psicología }\end{array}$ & 5 \\
\hline $\begin{array}{l}\text { 26. The British Journal of } \\
\text { Psychiatry }\end{array}$ & 5 \\
\hline
\end{tabular}

available for the period from 2001 to 2010 (Garcia, López \& Triana, 2014), several points can be highlighted. First, there was an increase in the number of publications with cooperation among Latin American authors, from 528 to 809 publications. Even considering that the present study covered a period of only five years, these figures indicate a growth of about $53 \%$ in the number of publications. While 520 articles were identified from 2001 to 2010, from 2011 to 2015, 770 articles were identified, an increase of $48 \%$ over a period of only five years. Latin American authorial participation increased from 2,154 in a decade (2011-2010) to 3,926 in a period of five years (2011-2015) growing 82, 3\%. In the first period (2001-2010), 105 thematic codes were used 623 times, and in the second period (2011-2015), 123 thematic codes were used 896 times, also indicating a thematic diversification in cooperative investigations.

Comparing both periods, authorial participation in cooperative publications increased for all countries, except Venezuela, even considering that we are comparing a decade with a period of five years. If we consider two groups (above and below 100 cooperative publications in 2011-2015), in the first group the countries which most increased their authorial participation were Cuba (79 to 205, or 159.5\%), Colombia (192 to 478, or 149.0\%) Argentina (308 to 672, or $118.2 \%)$, Chile (177 to 377 , or $113.0 \%)$, Mexico (367 to 624, or $70.0 \%$ ), Uruguay (88 to 133 , or $51.1 \%)$, Peru (111 to 167 , or $50.5 \%$ ), and Brazil (609 to 901, or 47.9\%). In the second group, the following changes were observed: Nicaragua (3 to 18, or $500.0 \%$ ), El Salvador (5 to 22 , or $340.0 \%$ ), Bolivia (10 to 29 , or $190.0 \%$ ), Ecuador (27 to 64, or $137.0 \%$ ), Paraguay (9 to 20 , or $122.2 \%$ ), Panama (8 to 15 , or $87.5 \%$ ), Guatemala (26 to 41 , or $57.7 \%$ ), Costa Rica (39 to 60 , or $53.8 \%$ ), Dominican Republic (18 to 26, or $44.4 \%)$, Honduras (24 to 26 , or $8.3 \%$ ). Only Venezuela presented a decrease in the period (54 to 48 , or less $11.1 \%$ ).

Even taking into account that data for 2001 2010 include 8 chapters out of 528 publications and data for 2011-2015 only include 770 articles, there is an increase in exclusively Latin American partnerships (281 to 318), especially in bilateral cooperation (251 to 289), what was not observed in cooperation involving three countries (23 and 23) or involving four or more 
countries (7 to 6). The most significant increase occurred in Latin American publications with third parties, from 247 to 452, with an increase in the Pan-American partnerships from 84 to 118 publications, and in Ibero-American publications from 12 to 47 and especially in other international partnerships, from 151 to 287 publications. The participation of the USA and Canada increased from 52 and 12 to 105 and 20 publications, respectively. Spanish authorial participations jumped from 12 to 45 and Portugal appeared in six publications in the period 2011-2015, what had not occurred in the period 2001-2010.

The three thematic areas most frequently investigated remain Physical and Psychological Disorders (176 to 283 publications), Health and Mental Health: Treatment and Prevention (100 to 137 publications) and Physiological Psychology and Neurosciences (82 to 94 publications). Almost all other areas showed some advance, including Psychometrics, Statistics and Methodology (44 to 77), Personality Psychology (8 to 25 publications), Educational Psychology (21 to 39), Industrial and Organizational Psychology (12 to 21), Consumer Psychology (5 to 16), Developmental Psychology (27 to 35), Professional Psychological and Health Personnel Issues (20 to 21), Human Experimental Psychology (16 to 23), Intelligent Systems (5 to 11), Communication Systems (2 to 4), Social Psychology (3 to 11 ), Sports and Leisure Psychology $(0$ to 4), Engineering and Environmental Psychology (6 to 7), Forensic Psychology and Legal Issues (1 to 4), Military Psychology (1 to 3). General Psychology remained with the same number of publications in both periods ( 2 and 2 ). In a few cases, the number of publications in cooperation decreased, e.g. Social Processes and Social Issues (48 to 46) and Animal Experimental and Comparative Psychology (44 to 33).

If we consider 40,7 as the average number of publications per area, than 17 out of 22 areas are below the average and cooperation could be fostered (General Psychology, Human Experimental Psychology, Animal Experimental and Comparative Psychology, Psychology and the Humanities, Communication Systems, Developmental Psychology, Social Psychology, Personality Psychology, Professional Psychological and Health Personnel Issues, Educational Psychology, Industrial and Organizational Psychology, Sport Psychology and Leisure, Military Psychology, Consumer Psychology, Engineering and Environmental Psychology, Intelligent Systems, and Forensic Psychology and Legal Issues).

Important changes have also occurred in the journals responsible for publishing works in cooperation between Latin American authors. The total number of journals rose from 252 to 354 . The number of journals publishing only one article also increased (157 to 207) as well as those publishing two or more articles (95 to 147). The number of journals responsible for publishing five or more articles in cooperation also increased (16 to 26). The most important journal remained the same (Revista Latino-Americana de Enfermagem), with 62 articles published from 2001-2010 and 33 articles from 2011-2015. As in the previous decade, most journals were on Neuroscience, Psychiatry, Nursing and Medicine. In both periods, only three Latin American journals on Psychology appear.

Comparing both periods, only six journals with five or more publications from the period 2001-2010 are still present in the period 2011-2015 (Revista Latino-Americana de Enfermagem, British Journal of Psychiatry, Revista Latinoamericana de Psicología, Journal of Multivariate Analysis, The Lancet and Psychological Medicine), but 20 new journals with five or more articles with Latin American cooperation were registered.

The scientific production and integration of Psychology in Latin America have attracted the attention of different authors (Martínez, 2008; Puche-Navarro, 2008; Livia, 2008; Koller, Sarriera \& Silva Neto, 2008). Scientific cooperation is an important instrument of integration between researchers in Psychology and related sciences in Latin America. Despite the evolution of cooperation, several areas of Latin American Psychology still lack international and regional cooperation, and actions are needed to increase this collaboration with the establishment and maintenance of cooperation networks (LópezLópez et al., 2010; Lopez-López et al., 2011 1).

It is necessary to move towards an integrated Latin American Psychology, to deal with specific Latin American issues, in different fields. The small number of journals on Psychology, and the comparatively small number of publications resulting from Latin American cooperation in Psychology also deserve further qualitative investigations to understand the barriers and potential opportunities for developing cooperation in more traditional psychological investigations. 
Further investigations should also analyze how Latin American cooperation in Psychology could contribute to solve local and national issues. In this case, it should be interesting to analyze how international cooperation, and especially Latin American international cooperation, are focused on problems of developed countries or they represent a contribution to solve national and regional problems (Zanotto, Haeffner, \& Guimarães, 2016; Kreimer, 2016). It is possible to suppose that regional cooperation may be much more sensitive to local and regional problems, shared by the Latin American community.

\section{- FINAL REMARKS}

The data indicate that cooperation in the Behavioral Sciences involving two or more countries in Latin America is increasing, in the number of publications, authorial participations, thematic diversity, and journals involved. The cooperation, however, is not homogeneous. Compared to Neurosciences and Psychiatry, the expansion in cooperation in different fields of Latin American Psychology should be pursued.

\section{- Conflict of interest}

The authors declare no conflict of interest.

\section{REFERENCES}

Allen, L., Brand, A., Scott, J., Altman, M., \& Hlava, M. (2014). Credit where credit is due. Nature, 508, 312-313. https://doi.org/10.1038/508312a

Cuartas, G. V., Arias, D. L., \& Leydesdorff, L. (2016). Regional and global science: Publications from Latin America and the Caribbean in the Scielo citation index and the Web of Science. El profesional de la información, 25(1), 35-46. https://doi.org/10.3145/epi.2016.ene.05

García, A., Acevedo-Triana, C. A., \& LópezLópez, W. (2015). The meaning of and proposals for Latin-American cooperation in psychology. Psykhe, 24(2), 1-12. http://dx.doi. org/10.7764/psykhe.24.2.765

García, A., Andres Acevedo-Triana, C., \& LopezLopez, W. (2014). Cooperation in the Latin American behavioral sciences: A Documentary Study. Terapia Psicologica, 32(2), 165 174.http://dx.doi.org/10.4067/S0718-

\section{9}

García, A., López-López, W., Acevedo-Triana, C. A., \& Bucher-Maluschke, J. S. N. F. (2016). Cooperation in the Latin American behavioral sciences: Motivation, evaluation and difficulties. Suma Psicológica, 23(2), 125-132. https://doi. org/10.1016/i.sumpsi.2016.08.002

García-Martínez, A. T., Guerrero-Bote, V., \& MoyaAnegón, F. (2012). World scientific production in psychology. Universitas Psychologica, 17 (3), 699-717. Retrieved from http://revistas. javeriana.edu.co/index.php/revPsycho/article/ view/699/2865

Katz, J., \& Martin, B. R. (1997). What is Research Collaboration? Research Policy, 26(1), 1-18. https://doi.org/10.1016/S00487333(96)00917-1

Khor, K. A., \& Yu, L. G. (2016). Influence of international co-authorship on the research citation impact of young universities. Scientometrics, 107(3), 1095-1110. https:// doi.org/10.1007/s $11192-016-1905-6$

Kliegl, R., \& Bates, D.M. (2011). International cooperation in psychology is on the rise. Scientometrics, 87(1), 149-158. https://doi. org/10.1007/s $11192-010-0299-0$

Koller, S. H., Sarriera, J. C., \& Silva Neto, N. A. (2008). A psicologia na América Latina: Um recorte da investigação e da pós-graduação. Interamerican Journal of Psychology, 42(3), 407-410. Retrieved from http://pepsic. bvsalud. org/pdf/rip/v42n3/es v42n3a01.pdf

Kreimer, P. (2016). Co-producing Social Problems and Scientific Knowledge. Chagas Disease and the Dynamics of Research Fields in Latin America. In M. Merz \& P. Sormani (Eds.), The local configuration of new research fields (pp. 173-190). London, UK: Springer. https://doi. org/10.1007/978-3-319-22683-5 10

Lemarchand, G. A. (2016). The Scientific Productivity and the Dynamics of Self-organizing Networks: Ibero-American and Caribbean Countries (1966-2013). In: H. Horta, M. Heitor, \& J. Salmi (Eds.). Trends and challenges in science and higher education: Building capacity in Latin America (Vol. 3, pp. 29-46). New York: Springer. https://doi.org/10.1007/978-3-319-2096472 
Livia, J. (2008). La producción científica y los estudios de post grado en psicología en el Perú. Retos en tiempos de reforma de salud [The scientific production and the postgraduate studies in psychology in Peru]. Interamerican Journal of Psychology, 42(3), 431-445. Retrieved from http://pepsic.bvsalud.org/pdf/ rip/v42n3/v42n3a03.pdf

López, W. L., García-Cepero, M. C., Bustamante, M. C. A., Silva, L. M., \& López, E. A. (2010). Panorama general de la producción académica en la psicología Iberoamericana, 2005-2007 [General overview of academic production in Ibero-American psychology, 2005-2007]. Papeles del Psicólogo, $37(3)$, 296-309. Retrieved from http://www. papelesdelpsicologo. es/pdf/1859.pdf

López, W.L., Silva, L.M., García-Cepero, M. C., Bustamante, M. C. A., \& López, E. A. (2011). Retos para la colaboración nacional e internacional en la psicología latinoamericana: Un análisis del sistema RedALyC, 2005-2007 [Challenges for national and international collaboration in Latin-American psychology: An analysis of the Redalyc system, 2005-2007]. Estudos de Psicologia, 16(1), 17-22. https://doi. org/10.1590/s1413-294×2011000100003

López-López, W., Anegón, F. D. M., AcevedoTriana, C., Garcia, A., \& Silva, L. M. (2015). Psychological research collaboration and visibility in Iberoamerica. Psicologia: Reflexão e Crítica, 28, 72-81. https://doi.org/10.1590/16787153.20152840011

López-López, W., Aguilar-Bustamante, M. C., Aguado-López, E., \& Becerril-García, A. (2016). Catálogo de revistas de Psicología Redalyc 2005-2014. Bogotá, Colombia: Asociación Colombiana para el Avance de las Ciencias del Comportamiento.

Mahoney, K. T., Buboltz, W. C., Jr., Calvert, B., \& Hoffmann, R. (2010). Research Productivity in Select Psychology Journals, 1986-2008. Journal of Psychology: Interdisciplinary and Applied, 144, 361-411. https://doi.org/10.10 80/00223980.2010.480901

Martínez, M. R. (2008). La psicología en Paraguay, contexto histórico: Retos para una Integración en escenarios latinoamericanos [The psychology in
Paraguay, challenges for an integration in Latin American scenarios]. Revista Interamericana de Psicología/Interamerican Journal of Psychology, 42(3), 472-480. Retrieved from http://pepsic. bvsalud.org/pdf/rip/v42n3/v42n3a06.pdf

Puche-Navarro, R. (2008). Trazos para un panorama de los postgrados y la investigación en psicología en Colombia [Review about postgraduate and research on psychology in Colombia]. Interamerican Journal of Psychology, 42(3), 415-430. Retrieved from http://pepsic. bvsalud.org/pdf/rip/v42n3/v42n3a02.pdf

Quevedo-Blasco, R., \& López-López, W. (2011). Situación de las revistas iberoamericanas de Psicología en el Journal Citation Reports de 2010. Universitas Psychologica, 10(3), 937947.

Ronda-Pupo, G. A., Díaz-Contreras, C., RondaVelázquez, G., \& Ronda-Pupo, J. C. (2015). The role of academic collaboration in the impact of Latin-American research on management. Scientometrics, 102(2), 1435-1454. https:// doi.org/10.1007/s $11192-014-1486-1$

Wagner, C. S. (2006). International collaboration in science and technology: promises and piffalls. In L. Box \& R. Engelhard (Eds.). Science and technology policy for development, dialogues at the interface (pp. 165-176). London, UK: Anthem Press.

Wagner, C. S., Park, H. W., \& Leydesdorff, L. (2015) The continuing growth of global cooperation networks in research: A conundrum for national governments. PLOS ONE, 10(7), e0131816. https://doi.org/10.1371/journal. pone.0131816

Zanotto, S. R., Haeffner, C., \& Guimarães, J. A. (2016). Unbalanced international collaboration affects adversely the usefulness of countries' scientific output as well as their technological and social impact. Scientometrics, 109(3), 1789-1814 https://doi.org/10.1007/s 11192 016-2126-8 .

Zych,I., \&Buela-Casal, G. (2010). Internacionalidad de las revistas de psicología multidisciplinar editadas en Iberoamérica e incluidas en la Web of Science. Universitas Psychologica, 9(1), 27. 34. 